University of Nebraska - Lincoln

DigitalCommons@University of Nebraska - Lincoln

2-16-2005

\title{
Apparent soil electrical conductivity: applications for designing and evaluating field-scale experiments
}

C. K. Johnson

University of Nebraska - Lincoln

Kent M. Eskridge

University of Nebraska - Lincoln, keskridge1@unl.edu

D. L. Corwin

USDA-ARS GEBJ Salinity Laboratory, 450 West Big Springs Road, Riverside, CA

Follow this and additional works at: https://digitalcommons.unl.edu/natrespapers

Part of the Natural Resources and Conservation Commons

Johnson, C. K.; Eskridge, Kent M.; and Corwin, D. L., "Apparent soil electrical conductivity: applications for designing and evaluating field-scale experiments" (2005). Papers in Natural Resources. 55.

https://digitalcommons.unl.edu/natrespapers/55

This Article is brought to you for free and open access by the Natural Resources, School of at DigitalCommons@University of Nebraska - Lincoln. It has been accepted for inclusion in Papers in Natural Resources by an authorized administrator of DigitalCommons@University of Nebraska - Lincoln. 


\title{
Apparent soil electrical conductivity: applications for designing and evaluating field-scale experiments
}

\author{
C.K. Johnson ${ }^{\mathrm{a}, *}$, K.M. Eskridge ${ }^{\mathrm{b}}$, D.L. Corwin ${ }^{\mathrm{c}}$ \\ a University of Nebraska, Lincoln, NE, USA \\ b Department of Biometry, University of Nebraska, 103 Miller Hall, Lincoln, NE 68583-0712, USA \\ ${ }^{\mathrm{c}}$ USDA-ARS GEBJ Salinity Laboratory, 450 West Big Springs Road, Riverside, CA 92507-4617, USA
}

\begin{abstract}
On-farm field-scale research has become increasingly common with the advent of new technologies. While promoting a realistic systems perspective, field-scale experiments do not lend themselves to the traditional design concepts of replication and blocking. Previously, a farm-scale dryland experiment in northeastern Colorado was conducted to evaluate apparent electrical conductivity $\left(\mathrm{EC}_{\mathrm{a}}\right)$ classification (within-field blocking) as a basis for estimating plot-scale experimental error. Comparison of meansquare (MS) errors for several soil properties and surface residue mass measured at this site, with those from a nearby plot-scale experiment, revealed that $\mathrm{EC}_{\mathrm{a}}$-classified within-field variance approximates plot-scale experimental error. In the present study, we tested these findings at a second and disparate experimental site, Westlake Farms (WLF) in central California. This 32 ha site was $\mathrm{EC}_{\mathrm{a}}$ mapped and partitioned into four and five classes using a response-surface model. Classification based on $\mathrm{EC}_{\mathrm{a}}$ significantly delineated most soil properties evaluated $(0-0.3 \mathrm{and} / \mathrm{or} 0-1.2 \mathrm{~m})$ and effectively reduced MS error $(P \leq 0.10)$. The MS's for several soil properties evaluated at the site were then compared with those of an associated plot-scale experiment; most MS's were not significantly different between the two levels of scale $(P \leq 0.05)$, corroborating results from the Colorado experiment. These findings support the use of within-field $\mathrm{EC}_{\mathrm{a}}$-classified variance as a surrogate for plot-scale experimental error and a basis for roughly evaluating treatment differences in non-replicated field-scale experiments. This alternative statistical design may promote field-scale research and encourage a reversal in research direction wherein research questions identified in field-scale studies are pursued at the plot-scale. (C) 2004 Elsevier B.V. All rights reserved.
\end{abstract}

Keywords: Agricultural systems; Classified management maps; Statistical analyses; Geographic information systems; Soil electrical conductivity

\footnotetext{
* Corresponding author. Present address: 11416 County Road 63, Sterling, CO 80751, USA. Tel.: +1970 522 2082; fax: +1 9705228988 .

E-mail address: cjohnson@kci.net (C.K. Johnson).
} 


\section{Introduction}

In recent years, heightened understanding of the interdependence between farm economics, environmental quality, and production potential has encouraged the expansion of agronomic research to evaluate farm management as it impacts an agroecosystem. Systems research can be defined as an experimental approach used to broadly appraise land management for a variety of short- and long-term outcomes that may include economic return; sociological implications; soil biological response, chemical composition, and physical structure; crop biomass and yield; pest pressure; and off-site environmental consequences. Moreover, global positioning systems (GPS), geographic information systems (GIS), and field-scale sensors allow examination of temporal shifts in many of these factors within a spatial context. Largely due to these technologies, systems research is increasingly conducted on farms at the field scale (Fraisse et al., 2001; Johnson et al., 2001; Mueller et al., 2002; Corwin et al., 2003b).

Systems research provides the "opportunity to test broad, integrated hypotheses" (Drinkwater, 2002, p. 355). Experiments typically involve multidisciplinary teams of researchers and rely on farmer input for planning, execution, and evaluation. Farmer involvement minimizes (1) research trials that prove ineffective on farms, and (2) rejection of experiment station trials that might have performed well on farms (Stroup et al., 1993). Field-scale systems experiments may hasten the adoption of sustainable management practices because positive outcomes are demonstrated at a scale to which farmers can relate (Rzewnicki, 1991).

To identify best management practices, the traditional research model uses highly controlled small-plot experiments, followed by multiple location trials (still using small plots), and finally realistic on-farm systems experiments. Yet, many investigators now suggest that research direction be reversed to begin with the system (Sumberg and Okali, 1988; Hargrove and Pickering, 1992; Johnson et al., 2003b), a strategy particularly appropriate for experiments in site-specific management (Vanden Heuvel, 1996; Crawford et al., 1997) and for assessing management-induced changes in soil, water, and air quality at farm or regional scales (Nielsen et al., 1995). Field-scale experiments used to broadly evaluate new management approaches can be followed by controlled small-plot experiments to test the nuances of system response.

A major barrier to field-scale experimentation is the perception of excessive and unmanageable variability. An acceptable level of experimental error has been documented in several experiments involving research plots up to $36 \mathrm{~m} \times 366 \mathrm{~m}$ (Rzewnicki et al., 1988), plots large enough to accommodate typical farm equipment. Yet, these experiments used replication and randomization, design features rarely feasible in increasingly larger experiments. One of the greatest limitations to field-scale experimentation is a dearth of acceptable methods for design and statistical evaluation.

Experimental error is the "failure of repeated observations, under similar conditions, to be identical" (LeClerg et al., 1962), and soil heterogeneity is the principle source in agronomic research (Harris, 1915). In classic experimentation, small plots are arranged in a randomized complete block design where blocks serve to increase precision by reducing experimental error due to soil heterogeneity. Blocks are placed in homogeneous areas based upon measurements of yield-significant properties. While topography, soil fertility, and 


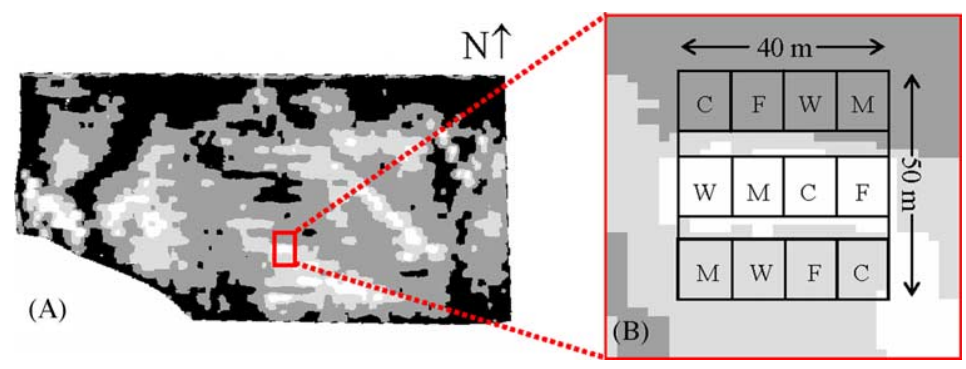

Fig. 1. Relationship between bulk soil electrical conductivity $\left(\mathrm{EC}_{\mathrm{a}}\right)$ classification and plot-scale blocking. (A) An $\mathrm{EC}_{\mathrm{a}}$-classified map of $\mathrm{a} \approx 32$ ha field at the Farm-Scale Intensive Cropping Study and (B) a typical plot-scale experiment identified within the field using $\mathrm{EC}_{\mathrm{a}}$ classification as a basis for blocking.

soil series exemplify traditional blocking factors, any method can be used that effectively partitions an existing fertility gradient. In some cases, apparent soil electrical conductivity $\left(\mathrm{EC}_{\mathrm{a}}\right)$ mapping can be used for this purpose.

Soil factors affecting $\mathrm{EC}_{\mathrm{a}}$ vary among locations and may include one or more of the following: salinity, clay type and percentage, bulk density, moisture, and temperature (Rhoades et al., 1989). In locations where soil factors contributing to $\mathrm{EC}_{\mathrm{a}}$ are also yield limiting, classified $\mathrm{EC}_{\mathrm{a}}$ maps can be used to design and place plot-scale experiments (Fig. 1). This is appropriate because $\mathrm{EC}_{\mathrm{a}}$ classes are related to outcome (crop yield) differences expected in the absence of treatments, the rationale for blocking. Classified $\mathrm{EC}_{\mathrm{a}}$ maps have been used to identify homogeneous areas within a field to both locate and block plot-scale experiments (personal communication, Newell Kitchen).

At the Farm-Scale Intensive Cropping Study (FICS) in northeastern Colorado significant relationships were found between $\mathrm{EC}_{\mathrm{a}}$, soil characteristics, and crop yields (Johnson et al., 2001, 2003c), supporting $\mathrm{EC}_{\mathrm{a}}$-classified zones as a basis for blocking and statistically evaluating plot-scale experiments. Background information for the FICS is provided in Table 2. At the FICS, $\mathrm{EC}_{\mathrm{a}}$ zones provided a framework through which measurements taken at different levels of scale (microbe, sampling-site, field, and farm) can be integrated (Johnson et al., 2004). Johnson et al. (2003b) hypothesized that if $\mathrm{EC}_{\mathrm{a}}$ classification can be used to block plot-scale experiments, $\mathrm{EC}_{\mathrm{a}}$-classified within-field blocking can be used to statistically evaluate field-scale experiments.

Fig. 1 illustrates a clear relationship between $\mathrm{EC}_{\mathrm{a}}$-partitioned soil heterogeneity at the plot and field scales. The 32 ha field shown on the left is separated into four classes of $\mathrm{EC}_{\mathrm{a}}$ (A), three of which form the basis for blocks in the traditional plot-scale experiment set in a randomized complete block design (B). Since blocks are homogeneous, plots need not be adjacent but could be placed anywhere in field (A) within assigned blocks. Thus, the entire 32 ha field can be conceptualized as an enlarged version of the plot-scale experiment, where within $\mathrm{EC}_{\mathrm{a}}$-class variance is equivalent to experimental error in the plot-scale experiment. To test this, Johnson et al. (2003b) evaluated numerous soil physical, chemical, and biological properties measured at both the FICS and a nearby traditional plot-scale experiment (Peterson et al., 1993). The $\mathrm{EC}_{\mathrm{a}}$-classified within-field mean square error (MS) of each property measured at the FICS was compared with MS error (derived from blocking) for that property measured in the plot-scale experiment. Experimental errors were similar, 
Table 1

Within apparent electrical conductivity $\left(\mathrm{EC}_{\mathrm{a}}\right)$ class means and significance for selected soil properties $(0-30 \mathrm{~cm}$ depth) measured at the Farm-Scale Intensive Cropping Study

\begin{tabular}{|c|c|c|c|c|c|c|c|c|c|c|}
\hline & \multirow{2}{*}{$\begin{array}{l}\mathrm{EC}_{\mathrm{a}} \text { ranges } \\
\left(\mathrm{dS} \mathrm{m}^{-1}\right)\end{array}$} & \multicolumn{6}{|c|}{ Productivity-associated factors } & \multicolumn{3}{|c|}{ Erosion-associated factors } \\
\hline & & $\begin{array}{l}\text { Water } \\
\text { content } \\
\left(\mathrm{kg} \mathrm{kg}^{-1}\right)\end{array}$ & $\begin{array}{l}\mathrm{SOM}^{\mathrm{a}} \\
\left(\mathrm{Mg} \mathrm{ha}^{-1}\right)\end{array}$ & $\begin{array}{l}\text { Total C } \\
\left(\mathrm{Mg} \mathrm{ha}^{-1}\right)\end{array}$ & $\begin{array}{l}\text { Total N } \\
\left(\mathrm{Mg} \mathrm{ha}^{-1}\right)\end{array}$ & $\begin{array}{l}\mathrm{P}^{\mathrm{a}} \\
\left(\mathrm{kg} \mathrm{ha}^{-1}\right)\end{array}$ & $\begin{array}{l}\mathrm{PMN}^{\mathrm{a}} \\
\left(\mathrm{kg} \mathrm{ha}^{-1}\right)\end{array}$ & $\begin{array}{l}\text { Bulk } \\
\text { density } \\
\left(\mathrm{g} \mathrm{cm}^{-3}\right)\end{array}$ & Clay $(\%)$ & $\mathrm{pH}$ \\
\hline $\mathrm{EC}_{\mathrm{a}}$ zone & & * & *** & $* *$ & $* *$ & $* *$ & $*$ & + & $*$ & *** \\
\hline Low & $0.00-0.17$ & 0.207 & 124.8 & 43.8 & 4.08 & 111.8 & 86.4 & 1.32 & 22.8 & 6.33 \\
\hline Medium low & $0.12-0.23$ & 0.187 & 115.9 & 35.2 & 3.45 & 69.2 & 67.0 & 1.39 & 24.3 & 6.42 \\
\hline Medium high & $0.14-0.29$ & 0.185 & 110.4 & 32.2 & 3.09 & 27.8 & 59.3 & 1.39 & 27.3 & 6.72 \\
\hline High & $0.18-0.78$ & 0.178 & 112.6 & 32.7 & 3.10 & 26.7 & 54.4 & 1.42 & 28.1 & 6.92 \\
\hline
\end{tabular}

a SOM: total soil organic matter; P: extractable P; PMN: potentially-mineralizable $\mathrm{NH}_{4}{ }^{+}$.

+ Comparisons of $\mathrm{EC}_{\mathrm{a}}$ class treatments are significant at the 0.10 level.

* Comparisons of $\mathrm{EC}_{\mathrm{a}}$ class treatments are significant at the 0.05 level.

** Comparisons of $\mathrm{EC}_{\mathrm{a}}$ class treatments are significant at the 0.01 level. 
indicating that field-scale $\mathrm{EC}_{\mathrm{a}}$-classified variability effectively estimated soil heterogeneity partitioned by plot-scale blocking. These findings support the use of field-scale systems experiments to broadly evaluate treatments and identify research needs requiring further study at the plot scale.

The geographic extent to which these results are transferable remains untested. Data sets suitable for assessment are difficult to find because they must meet two criteria. First, data must include a variety of soil indices from both an $\mathrm{EC}_{\mathrm{a}}$-classified field-scale site and an associated blocked plot-scale experiment. Second, the soil characteristics driving $\mathrm{EC}_{\mathrm{a}}$ at the sites must be yield limiting. Data sets from 32.4 and 8.1 ha sites at Westlake Farms (WLF) in the San Joaquin Valley of central California met these criteria (Corwin et al., 2003a,b). A positive correlation between $\mathrm{EC}_{\mathrm{a}}$ and cotton yield at $\mathrm{WLF}(r=0.51 ; P \leq 0.01)$ (Corwin et al., $2003 b$ ) indicates potential utility of $\mathrm{EC}_{\mathrm{a}}$ classification as a basis for blocking. The objective of this paper was to determine whether $\mathrm{EC}_{\mathrm{a}}$-classified within-field variability can be used to approximate plot-scale experimental error in a second and contrasting environment, the San Joaquin Valley.

\section{Materials and methods}

\subsection{Field-scale study}

The WLF study site is a 32.4 ha field located on the west side of California's San Joaquin Valley and comprised of Panoche silty clay thermic Xerothents soil. The site has been used in a drainage water reuse study since 1999. Eight 4 ha rectangular paddocks with dimensions of $75 \mathrm{~m} \times 364 \mathrm{~m}$ comprise the study site (Fig. 2A). To characterize the spatial variability of soil properties, an $\mathrm{EC}_{\mathrm{a}}$ survey was conducted in 1999 using an EM-38 electrical conductivity meter (Geonics, Ltd., Mississauga, Ontario, Canada) ${ }^{1}$ following the survey guidelines outlined by Corwin and Lesch (2003). Approximately $4000 \mathrm{EC}_{\mathrm{a}}$ measurements were taken across the site.

The $\mathrm{EC}_{\mathrm{a}}$ survey consisted of a grid of 384 sites arranged in a $4 \times 12$ pattern within each of the eight paddocks. At each site, $\mathrm{EC}_{\mathrm{a}}$ measurements were taken using electromagenetic induction $(E M)$ with the coil configuration oriented in the vertical $\left(\mathrm{EM}_{\mathrm{V}}\right)$ and in the horizontal $\left(\mathrm{EM}_{\mathrm{h}}\right)$ position. The horizontal coil configuration concentrates the EM reading nearer to the soil surface and penetrates to a depth of roughly $0.75-1.0 \mathrm{~m}$, whereas the EM reading in the vertical configuration penetrates to a depth of roughly $1.5 \mathrm{~m}$ and concentrates the reading less at the surface. From the EM measurements the geometric mean and profile ratio were calculated for each site. The geometric mean EM levels were defined as the SQRT $\left(E M_{v} \times E M_{h}\right)$. The profile ratios were defined as $E_{h} / E M_{v}$. In essence, the profile ratio is analogous to the leaching fraction, while the geometric mean approximates relative salinity in the root zone (Corwin et al., 1999).

Utilizing the EM data and ESAP statistical software (ESAPv2.0) developed by Lesch et al. (1995), 40 soil sampling sites were selected by means of a response surface sample

\footnotetext{
${ }^{1}$ Mention of a trademark, proprietary product or vendor does not constitute a guarantee of or warranty of the product by USDA nor imply its approval to the exclusion of other products that may be suitable.
} 


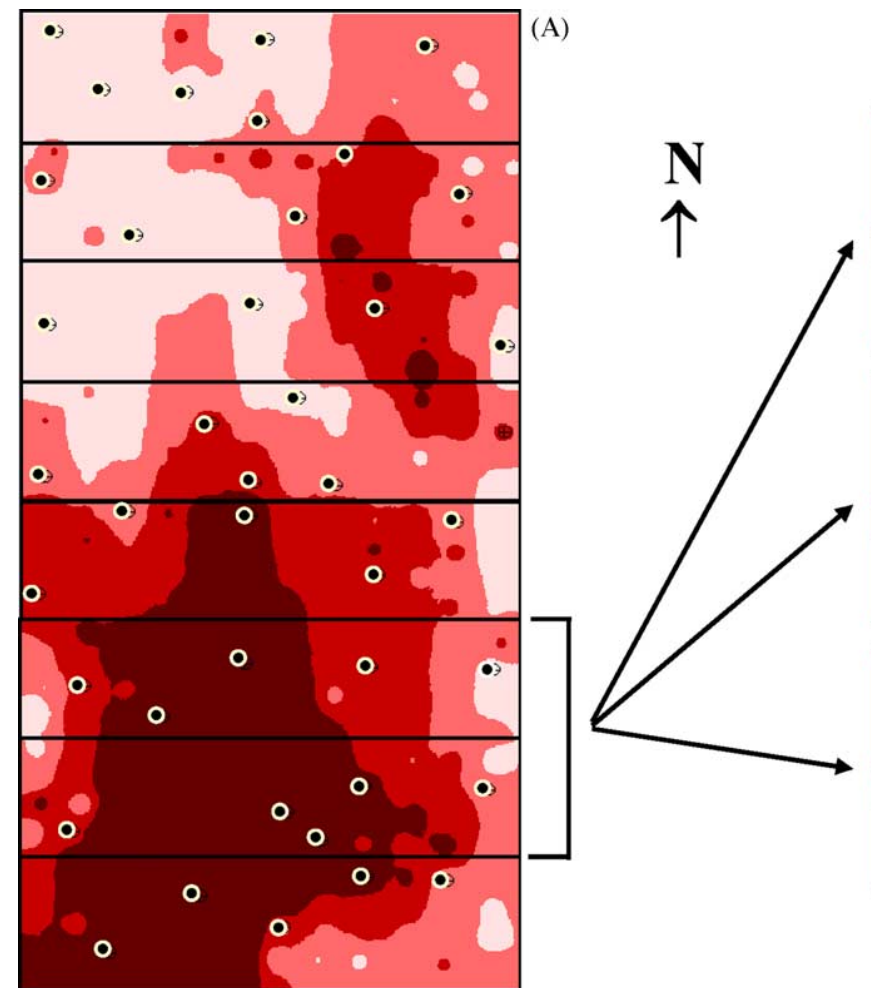

Fig. 2. The 32.4 ha field-scale Westlake Farms Study separated into eight paddocks (A). The site is partitioned into four classes of apparent electrical conductivity $\left(\mathrm{EC}_{\mathrm{a}}\right.$ ) based upon a response surface. Class color, from light to dark, corresponds to increasing conductivity. Forty soil sampling points ( $)$ are identified. Two paddocks on the south end of the study site were selected for more intensive soil sampling and were used to simulate a traditional plot-scale study (8.1 ha) (B). These are shown with three different blocking schemes (three, four, and six blocks) superimposed over a map of laboratory-measured salinity $\left(\mathrm{EC}_{\mathrm{e}}\right.$ ). Light to dark coloration indicates low to high salinity where salinity ranges are: $6.988-13.288,13.288-18.42,18.42-26.435$, and $26.435-35.6 \mathrm{dS} \mathrm{m}^{-1}$ for the four zones shown. Thirty randomly selected soil sampling sites, in addition to the ten response surface sites, are identified on each map ( 
design (Fig. 2). Conceptually, 40 sites were selected to characterize the observed spatial variability in EM measurements that satisfy the following three criteria: (i) to represent about $95 \%$ of the observed range in the geometric mean EM data, (ii) to represent about $95 \%$ of the observed range in the EM profile ratio data, and (iii) to be spatially distributed across the eight paddocks in an approximately uniform manner with about five sites within each paddock. A more detailed discussion on how a spatial response surface sample design is used to simultaneously achieve these criteria is found in Lesch et al. (1995).

At each of the 40 sites, soil core samples were taken in 1999 and again in 2002. Soil cores were taken at 0.3 and $1.2 \mathrm{~m}$ depth increments and analyzed for a variety of physical and chemical soil properties listed in Table 3. Methods of analysis are provided by Corwin et al. (2003a). The 2002 data set was used for this study with the exception of soil texture and bulk density assessments, which were only available in the 1999 data set.

The WLF field-scale experiment was partitioned into four and five $\mathrm{EC}_{\mathrm{a}}$ classes. To accomplish this, $\mathrm{EM}_{\mathrm{V}}$ and $\mathrm{EM}_{\mathrm{h}}$ measurements were $\log$ transformed and decorrelated to determine principal component scores by the same process used in ESAP to create a response surface. Resultant scores were then separated into quartiles or quantiles. All spatial data were entered into a geographic information system (GIS) using the commercial GIS software ArcView 3.1 (ESRI, Redlands, CA). ${ }^{1}$

\subsection{Plot-scale study}

Two paddocks on the south end of the WLF study ( 8.1 ha) were used to simulate a typical plot-scale experiment set in a randomized complete block design (Fig. 2B). We selected salinity as the blocking factor because it is the major soil property limiting crop production at WLF (Corwin et al., 2003b), and it represents an obvious basis for a traditionally designed plot-scale experiment. Salinity was assessed for soil samples (0-1.2 m) from 40 sampling sites by measuring electrical conductivity in a 1:1 saturated paste $\left(\mathrm{EC}_{\mathrm{e}}\right)$. Soil analyses from all available sampling points within the two paddocks were evaluated to increase degrees of freedom. Consequently, thirty samples came from random sampling sites, selected using SAS (SAS Institute, 1997), while the remaining ten were taken from the response surface sites described above. Using ArcView 3.1 GIS software (ESRI, Redlands, CA) ${ }^{1}$, a map of $\mathrm{EC}_{\mathrm{e}}$ was produced, classified, and interpolated using inverse-distance-weighting, and the resulting $\mathrm{EC}_{\mathrm{e}}$ map used to position experimental blocks (Fig. 2).

\subsection{Experimental approach}

The same general approach taken at the FICS experiment in northeastern Colorado (Johnson et al., 2003b) was applied to the WLF study in central California. Within-field variability delineated using $\mathrm{EC}_{\mathrm{a}}$ classification (i.e. within-field blocking) was evaluated as an estimate of traditional small-plot experimental error. Our strategy was to compare fieldand plot-scale experimental error to determine the significance of scale to experimental outcome (crop yield) occurring in the absence of treatments.

Both field- and plot-scale experiments in this study were analyzed as complete blocks. The field-scale experiment was separated into four and five $\mathrm{EC}_{\mathrm{a}}$ classes, and the plot-scale experiment into three, four, and six $\mathrm{EC}_{\mathrm{e}}$ blocks (Fig. 2), numbers of blocks typically used in 
Table 2

Comparison of the Farm-Scale Intensive Cropping Study and the Westlake Farms research sites: site characteristics and $\mathrm{EC}_{\mathrm{a}}$ mapping/classification methods

\begin{tabular}{|c|c|c|}
\hline & $\begin{array}{l}\text { Farm-Scale Intensive Cropping } \\
\text { Study }^{\mathrm{a}}\end{array}$ & Westlake Farms Study ${ }^{\text {b }}$ \\
\hline Location & Northeast Colorado & Central California \\
\hline Climate & Semiarid & Arid \\
\hline Soil classification & $\begin{array}{l}\text { Platner, Weld, and Rago loam } \\
\text { (fine, smectitic, mesic Aridic } \\
\text { Paleustolls, Aridic Argiustolls, } \\
\text { and Pachic Argiustolls) }\end{array}$ & $\begin{array}{l}\text { Lethent clay loam (fine, } \\
\text { smectitic, thermic, Typic } \\
\text { Natrargid) }\end{array}$ \\
\hline Cropping system & $\begin{array}{l}\text { Dryland } \\
\text { Winter wheat-corn-proso } \\
\text { millet-fallow rotation }\end{array}$ & $\begin{array}{l}\text { Irrigated } \\
\text { Bermuda grass rotational forage }\end{array}$ \\
\hline \multirow[t]{3}{*}{ Regional production challenges } & $\begin{array}{l}\text { Maximizing } \\
\text { precipitation-use-efficiency }\end{array}$ & Saline drainage water disposal \\
\hline & Minimizing wind/water erosion & $\begin{array}{l}\text { Controlling toxic ion and trace } \\
\text { element buildup in soil and crops }\end{array}$ \\
\hline & $\begin{array}{l}\text { Maintaining/increasing soil } \\
\text { organic matter }\end{array}$ & Maintenance of soil quality \\
\hline Primary soil factors limiting yield & $\begin{array}{l}\text { Depth, organic matter, } \\
\text { water-holding capacity, } \mathrm{pH}\end{array}$ & $\begin{array}{l}\text { Salinity, leaching fraction, water } \\
\text { content, } \mathrm{pH}\end{array}$ \\
\hline Size of field-scale study site (ha) & 250 & 32.4 \\
\hline Size of plot-scale study site (ha) & 5.5 & 8.1 \\
\hline Depth of soil sampling (m) & 0.33 & 1.2 \\
\hline $\mathrm{EC}_{\mathrm{a}}$ collection method & Direct contact & $\begin{array}{l}\text { Electromagnetic induction: } \\
\text { horizontal }\left(\mathrm{EM}_{\mathrm{H}}\right) \text { and vertical } \\
\left(\mathrm{EM}_{\mathrm{V}}\right) \text { modes }\end{array}$ \\
\hline Range of measured $\mathrm{EC}_{\mathrm{a}}\left(\mathrm{dS} \mathrm{m}^{-1}\right)$ & $0.03-0.78$ & $\begin{array}{l}\mathrm{EM}_{\mathrm{H}}: 1.45-5.19 \\
\mathrm{EM}_{\mathrm{V}}: 2.56-7.95\end{array}$ \\
\hline $\mathrm{EC}_{\mathrm{a}}$ classification method & $\begin{array}{l}\text { Design-based } \\
\text { Unsupervised classification }\end{array}$ & $\begin{array}{l}\text { Model-based } \\
\text { Response surface }\end{array}$ \\
\hline \multirow{2}{*}{$\begin{array}{l}\text { Major soil factors driving } \mathrm{EC}_{\mathrm{a}} \text { (in } \\
\text { order of significance) }\end{array}$} & Percent clay & Salinity \\
\hline & $\begin{array}{l}\text { Bulk density } \\
\text { Water content } \\
\text { Salinity }\end{array}$ & $\begin{array}{l}\text { Water content } \\
\text { Bulk density } \\
\text { Percent clay }\end{array}$ \\
\hline
\end{tabular}

\footnotetext{
a Johnson et al. (2001, 2003a).
}

b Corwin et al. (2003a,b).

agronomic research. Different numbers of blocks (or classes) were analyzed to investigate the effect of block number on experimental error. The effectiveness of $\mathrm{EC}_{\mathrm{a}}$ as a blocking factor was evaluated in two ways using analysis of variance. First, the means of measured soil properties were pooled over the 40 sites and four depths. For each property, when within $\mathrm{EC}_{\mathrm{a}}$ class variability (MS (site(EC $\left(\mathrm{E}_{\mathrm{a}}\right.$ class)) ) was significantly smaller than among $\mathrm{EC}_{\mathrm{a}}$ class variability (MS ( $\mathrm{EC}_{\mathrm{a}}$ class)), blocking was considered effective for the property. Secondly, $\mathrm{EC}_{\mathrm{a}}$ classes were evaluated for their ability to significantly partition soil properties across the WLF site. 
Lastly, the $F$-test was used to compare $\mathrm{EC}_{\mathrm{a}}$-classified within-field MS error, for several soil properties assessed in the field scale experiment, to MS error derived from blocking for those same soil properties assessed at the plot scale. All statistical analyses were conducted using SAS (SAS Institute, 1997).

\section{Results and discussion}

\subsection{EC $C_{a}$ effectiveness as a blocking factor}

The effectiveness of $\mathrm{EC}_{\mathrm{a}}$ classification as a basis for blocking was evaluated from two perspectives. First, any successful blocking scheme will substantially reduce variability. For individual soil parameters measured at WLF, when within $\mathrm{EC}_{\mathrm{a}}$ class variability (MS (site $\left(\mathrm{EC}_{\mathrm{a}}\right.$ class $\left.)\right)$ ) was significantly smaller than among $\mathrm{EC}_{\mathrm{a}}$ class variability (MS $\left(\mathrm{EC}_{\mathrm{a}}\right.$ class)), $\mathrm{EC}_{\mathrm{a}}$-classified blocking was effective for the parameter. Using this criterion, $\mathrm{EC}_{\mathrm{a}}$ proved to be a suitable basis for blocking a majority of measured soil properties (Table 3). Secondly, Corwin et al. (2003b) identified four soil properties exhibiting the greatest effect on cotton yields at WLF, salinity, plant-available water, leaching fraction, and $\mathrm{pH}$. Three of these were evaluated in our study. The variability of salinity and $\mathrm{pH}$ (with separation into four or five $\mathrm{EC}_{\mathrm{a}}$ classes), and water content, an indicator of plant-available water (with separation into five $\mathrm{EC}_{\mathrm{a}}$ classes), was significantly reduced by $\mathrm{EC}_{\mathrm{a}}$ classification. The responsiveness of yield-associated soil parameters to $\mathrm{EC}_{\mathrm{a}}$ classification supports the use of $\mathrm{EC}_{\mathrm{a}}$ as a blocking factor because it verifies the relationship between $\mathrm{EC}_{\mathrm{a}}$ classes and outcome (yield) differences expected in the absence of treatments, the rationale for blocking.

Increasing the number of $\mathrm{EC}_{\mathrm{a}}$ classes from four to five did not significantly reduce within $\mathrm{EC}_{\mathrm{a}}$ class variability (MS (site $\left(\mathrm{EC}_{\mathrm{a}}\right.$ class)) ) for any of the soil properties evaluated (Table 3 ). However, partitioning into five classes produced a significant $F$-test (MS (EC $\mathrm{E}_{\mathrm{a}}$ class)/MS ( $\operatorname{site}\left(\mathrm{EC}_{\mathrm{a}}\right.$ class $\left.)\right)$ ) indicating effective blocking for water content, saturation percentage $(\mathrm{SP})$ and exchangeable sodium percentage (ESP), results not found with four classes. Conversely, partitioning into four classes effectively blocked cation exchange capacity (CEC), $\mathrm{CaCO}_{3}$, and exchangeable $\mathrm{K}^{+}$, results not found with five classes.

The effectiveness of $\mathrm{EC}_{\mathrm{a}}$ as a blocking variable was also evaluated for significant delineation of soil characteristics at two depths of measurement and using four and five classes of $\mathrm{EC}_{\mathrm{a}}$. With partitioning into four classes, a majority of measured soil properties were different among $\mathrm{EC}_{\mathrm{a}}$ classes $(P \leq 0.10)$ for both surface and root-zone soils $(0-0.33$ and 0-1.2 m depths) (Table 4). Increasing the number of $\mathrm{EC}_{\mathrm{a}}$ classes from four to five added water content and $\mathrm{pH}$ to the list of significantly partitioned soil properties at the surface, and saturation percentage and ESP to those significantly partitioned in deeper soils (data not shown).

\subsection{MS error comparisons: field-scale EC $C_{a}$ classification versus plot-scale blocking}

Comparisons of soil property MS errors, calculated for the field-scale experiment separated into four and five $\mathrm{EC}_{\mathrm{a}}$ classes, and the plot-scale experiment separated into three, four, 
Table 3

The 32.4 ha Westlake Study was partitioned into four and five classes based on apparent electrical conductivity $\left(\mathrm{EC}_{\mathrm{a}}\right)$

\begin{tabular}{|c|c|c|c|c|c|c|}
\hline \multirow[t]{2}{*}{ Soil property } & \multicolumn{3}{|l|}{$4 \mathrm{EC}_{\mathrm{a}}$ classes } & \multicolumn{3}{|l|}{$5 \mathrm{EC}_{\mathrm{a}}$ classes } \\
\hline & $\begin{array}{l}\text { MS }\left(\mathrm{EC}_{\mathrm{a}} \text { class }\right) \\
(\text { d.f. }=3)\end{array}$ & $\begin{array}{l}\text { MS }\left(\operatorname{site}\left(\mathrm{EC}_{\mathrm{a}} \text { class }\right)\right) \\
(\text { d.f. }=36)\end{array}$ & $\begin{array}{l}\text { MS (error) } \\
(\text { d.f. }=120)\end{array}$ & $\begin{array}{l}\left.\text { MS (EC }{ }_{a} \text { class }\right) \\
(\text { d.f. }=4)\end{array}$ & $\begin{array}{l}\text { MS }\left(\operatorname{site}\left(\mathrm{EC}_{\mathrm{a}} \text { class }\right)\right) \\
(\text { d.f. }=35)\end{array}$ & $\begin{array}{l}\text { MS (error) } \\
(\text { d.f. }=12)\end{array}$ \\
\hline Water content $\left(\mathrm{kg} \mathrm{kg}^{-1}\right)$ & 0.324 & 0.339 & 0.276 & $0.664^{+}$ & 0.301 & 0.276 \\
\hline $\operatorname{Sand}^{\mathrm{b}}(\%)$ & $1136^{*}$ & 197 & 92.8 & $738^{*}$ & 220 & 92.8 \\
\hline Silt $^{\mathrm{b}}(\%)$ & $637^{*}$ & 166 & 40.7 & $472^{*}$ & 172 & 40.7 \\
\hline Clay $^{\mathrm{b}}(\%)$ & 103 & 49.2 & 53.8 & 32.3 & 57.0 & 53.8 \\
\hline $\mathrm{SP}^{\mathrm{a}}(\%)$ & 519 & 256 & 117 & $710^{*}$ & 227 & 117 \\
\hline $\mathrm{pH}$ & $0.585^{*}$ & 0.126 & 0.077 & $0.449^{*}$ & 0.129 & 0.077 \\
\hline $\mathrm{EC}_{\mathrm{e}}{ }^{\mathrm{a}}\left(\mathrm{dS} \mathrm{m}^{-1}\right)$ & $1009^{*}$ & 67 & 53 & $940^{*}$ & 48 & 53 \\
\hline $\mathrm{CEC}^{\mathrm{a}}\left(\mathrm{mmol}_{\mathrm{c}} \mathrm{kg}^{-1}\right)$ & $2310^{*}$ & 510 & 190 & 1150 & 590 & 190 \\
\hline $\operatorname{ESP}(\%)$ & 1475 & 3155 & 1525 & $7327^{*}$ & 2534 & 1525 \\
\hline SAR & $5306^{*}$ & 442 & 325 & $5189^{*}$ & 317 & 325 \\
\hline Total C $\left(\mathrm{g} \mathrm{kg}^{-1}\right)$ & $2.850^{*}$ & 0.447 & 0.630 & $1.56^{*}$ & 0.525 & 0.630 \\
\hline Total N $\left(\mathrm{g} \mathrm{kg}^{-1}\right)$ & $0.0057^{*}$ & 0.00195 & 0.00437 & $0.00509^{*}$ & 0.00192 & 0.00437 \\
\hline Gypsum $\left(\mathrm{g} \mathrm{kg}^{-1}\right)$ & 179 & 171 & 155 & 291 & 158 & 155 \\
\hline $\operatorname{Mo}\left(\mathrm{mg} \mathrm{L}^{-1}\right)$ & 1.04 & 0.507 & 0.0938 & 0.812 & 0.518 & 0.0939 \\
\hline $\mathrm{B}\left(\mathrm{mg} \mathrm{L}^{-1}\right)$ & $356^{*}$ & 80.5 & 33.0 & $265^{*}$ & 83.1 & 33.0 \\
\hline \multicolumn{7}{|c|}{ Anions in the saturation extract } \\
\hline $\mathrm{Cl}^{-}\left(\mathrm{mmol}_{\mathrm{c}} \mathrm{L}^{-1}\right)$ & $5611^{*}$ & 896 & 428 & $5151^{*}$ & 814 & 428 \\
\hline $\mathrm{HCO}_{3}{ }^{-}\left(\mathrm{mmol}_{\mathrm{c}} \mathrm{L}^{-1}\right)$ & $6.176^{*}$ & 0.504 & 0.393 & $4.959^{*}$ & 0.481 & 0.393 \\
\hline $\mathrm{NO}_{3}{ }^{-}\left(\mathrm{mmol}_{\mathrm{c}} \mathrm{L}^{-1}\right)$ & 0.144 & 0.068 & 0.043 & 0.114 & 0.069 & 0.043 \\
\hline $\mathrm{SO}_{4}^{-}\left(\mathrm{mmol}_{\mathrm{c}} \mathrm{L}^{-1}\right)$ & $172,925^{*}$ & 10,020 & 8,208 & $15,7871^{*}$ & 7,086 & 8,208 \\
\hline
\end{tabular}


Cations in the saturation extract

$\begin{array}{llllll}\mathrm{Ca}^{2+}\left(\mathrm{mmol}_{\mathrm{c}} \mathrm{L}^{-1}\right) & 1.29 & 8.28 & 4.12 & 5.55 & 7.99 \\ \mathrm{~K}^{+}\left(\mathrm{mmol}_{\mathrm{c}} \mathrm{L}^{-1}\right) & 4.291^{*} & 0.649 & 0.127 & 5.375^{*} & 0.422 \\ \mathrm{Mg}^{2+}\left(\mathrm{mmol}_{\mathrm{c}} \mathrm{L}^{-1}\right) & 1721^{*} & 109 & 58 & 1170^{*} & 0.127 \\ \mathrm{Na}^{+}\left(\mathrm{mmol}_{\mathrm{c}} \mathrm{L}^{-1}\right) & 205,035^{*} & 12,835 & 10,252 & 191,248^{*} & 58\end{array}$

Exchangeable cations $\mathrm{Ca}^{2+}\left(\mathrm{mmol}_{\mathrm{c}} \mathrm{kg}^{-1}\right)$ $\mathrm{K}^{+}\left(\mathrm{mmol}_{\mathrm{c}} \mathrm{kg}^{-1}\right)$

$\mathrm{Mg}^{2+}\left(\mathrm{mmol}_{\mathrm{c}} \mathrm{kg}^{-1}\right)$

$1.88^{+}$

94.0

$\mathrm{Na}^{+}\left(\mathrm{mmol}_{\mathrm{c}} \mathrm{kg}^{-1}\right)$

117.7

$2550^{*}$

60.5

310

$\begin{array}{ll}153 & 186^{+} \\ 1.95 & 1.78 \\ 22.8 & 70.4 \\ 140 & 2690^{*}\end{array}$

81.0

0.830

64.2

230

Comparisons were made between among site (within $\mathrm{EC}_{\mathrm{a}}$ class) and among $\mathrm{EC}_{\mathrm{a}}$ class mean squares (MS's) for several soil properties using these classification schemes. The MS's were calculated on the means of measured soil properties pooled over 40 sites and four depths, $0-0.3,0.3-0.6,0.6-0.9$, and $0.9-1.2 \mathrm{~m}$ (160 observations).

${ }^{a} \mathrm{EC}_{\mathrm{e}}$ : laboratory-measured EC using a 1:1 water saturated paste; SP: saturation percentage; CEC: cation exchange capacity.

b Degrees of freedom for MS(EC class), 4 or 5 classes; MS (site(EC class)), 4 or 5 classes; and MS(error) are 3 or 4, 30 or 29 , and 102 for sand, silt, and clay, and 3 or 4, 31 or 30, and 105 for bulk density.

* MS (EC $\mathrm{a}_{\mathrm{a}}$ class) is significantly larger than MS (site( $\mathrm{EC}_{\mathrm{a}}$ class)) at the 0.05 level.

$+\mathrm{MS}\left(\mathrm{EC}_{\mathrm{a}}\right.$ class $)$ is significantly larger than $\mathrm{MS}$ ( $\operatorname{site}\left(\mathrm{EC}_{\mathrm{a}}\right.$ class $\left.)\right)$ at the 0.10 level. 
Table 4

Significance of $\mathrm{EC}_{\mathrm{a}}$ classification/EC $\mathrm{E}_{\mathrm{e}}$ blocking and comparison of soil property (0-0.3 $\mathrm{m}$ and 0-1.2 m depths) means and mean square errors (MSE's) within field-scale apparent electrical conductivity $\left(\mathrm{EC}_{\mathrm{a}}\right.$ ) classes (with partitioning into four classes) and plot-scale blocks (with partitioning into four blocks) at the Westlake Farms Study site

\begin{tabular}{|c|c|c|c|c|c|c|c|c|c|c|c|c|c|}
\hline \multirow[t]{3}{*}{ Soil property } & \multirow[t]{3}{*}{ Units } & \multicolumn{6}{|c|}{ Field-scale experiment } & \multicolumn{6}{|c|}{ Plot-scale experiment } \\
\hline & & \multicolumn{4}{|c|}{ Within $\mathrm{EC}_{\mathrm{a}}$ class means } & \multirow[t]{2}{*}{$\operatorname{Pr}>F$} & \multirow[t]{2}{*}{ MSE } & \multicolumn{4}{|c|}{ Within block means } & \multirow[t]{2}{*}{$\operatorname{Pr}>F$} & \multirow[t]{2}{*}{ MSE } \\
\hline & & $\mathrm{I}$ & II & III & IV & & & I & II & III & IV & & \\
\hline \multicolumn{14}{|l|}{$0-0.3 \mathrm{~m}$ depth } \\
\hline Water $^{\mathrm{b}}$ content & $\mathrm{kg} \mathrm{kg}^{-1}$ & 0.193 & 0.192 & 0.185 & 0.196 & n.s. & 0.136 & 0.199 & 0.201 & 0.188 & 0.233 & 0.02 & 0.102 \\
\hline Saturation percentage & $\%$ & 56.9 & 62.0 & 66.0 & 74.2 & 0.0001 & 46.7 & 73.8 & 79.0 & 72.3 & 66.1 & 0.001 & 39.4 \\
\hline $\mathrm{pH}$ & & 7.45 & 7.70 & 7.76 & 7.78 & n.s. & 0.125 & 7.93 & 8.00 & 7.83 & 7.74 & n.s. & 0.0666 \\
\hline CEC & $\mathrm{mmol}_{\mathrm{c}} \mathrm{kg}^{-1}$ & 177 & 185 & 217 & 240 & 0.02 & 2111 & 256 & 247 & 223 & 249 & n.s. & 3704 \\
\hline ESP & $\%$ & 23.4 & 36.3 & 33.2 & 50.6 & 0.03 & 399 & 34.7 & 55.5 & 44.0 & 18.7 & 0.02 & 583 \\
\hline SAR & & 12.8 & 17.5 & 23.5 & 42.0 & 0.0001 & 92.9 & 34.1 & 41.4 & 30.8 & 14.9 & 0.0001 & 123 \\
\hline Total C & $\mathrm{g} \mathrm{kg}^{-1}$ & 9.42 & 8.65 & 7.79 & 6.48 & 0.01 & 3.44 & 5.37 & 6.69 & 7.40 & 9.01 & n.s. & 1.87 \\
\hline Total N & $\mathrm{g} \mathrm{kg}^{-1}$ & 0.775 & 0.760 & 0.735 & 0.626 & n.s. & 0.0214 & 0.597 & 0.658 & 0.729 & 0.804 & 0.06 & $0.0092^{\mathrm{a}}$ \\
\hline $\mathrm{CaCO}_{3}$ & $\mathrm{~g} \mathrm{~kg}^{-1}$ & 20.9 & 14.5 & 10.6 & 5.16 & 0.008 & 92.1 & 1.13 & 1.33 & 6.67 & 11.1 & 0.0001 & $14.6^{\mathrm{a}}$ \\
\hline Gypsum & $\mathrm{g} \mathrm{kg}^{-1}$ & 23.0 & 36.4 & 34.7 & 59.3 & 0.0005 & 288 & 52.9 & 69.5 & 57.0 & 38.8 & 0.0004 & 159 \\
\hline Mo & $\mu \mathrm{g} \mathrm{L}^{-1}$ & 498 & 457 & 668 & 885 & n.s. & 275 & 657 & 817 & 493 & 345 & 0.006 & $81.9^{\mathrm{a}}$ \\
\hline Exchangeable $\mathrm{Na}^{+}$ & $\mathrm{mmol}_{\mathrm{c}} \mathrm{kg}^{-1}$ & 39.2 & 58.2 & 71.8 & 122 & 0.0001 & 852 & 101 & 108 & 97.0 & 94.7 & n.s. & 1002 \\
\hline
\end{tabular}




\begin{tabular}{|c|c|c|c|c|c|c|c|c|c|c|c|c|c|}
\hline \multicolumn{14}{|l|}{$0-1.2 \mathrm{~m}$ depth } \\
\hline Water content & $\mathrm{kg} \mathrm{kg}^{-1}$ & 0.241 & 0.249 & 0.233 & 0.254 & n.s. & 0.0845 & 0.251 & 0.249 & 0.248 & 0.260 & n.s. & 0.0497 \\
\hline Saturation percentage & $\%$ & 59.1 & 65.9 & 64.6 & 67.6 & n.s. & 64.0 & 69.6 & 66.9 & 65.0 & 62.9 & n.s. & 35.9 \\
\hline $\mathrm{pH}$ & & 7.74 & 7.94 & 8.02 & 7.94 & 0.008 & 0.0316 & 8.08 & 8.09 & 7.98 & 7.92 & 0.09 & 0.0275 \\
\hline $\mathrm{EC}_{\mathrm{e}}$ & $\mathrm{dS} \mathrm{m} \mathrm{m}^{-1}$ & 13.7 & 17.1 & 19.9 & 24.2 & 0.0001 & 16.7 & 20.7 & 27.8 & 25.3 & 16.0 & 0.0001 & 20.0 \\
\hline CEC & $\mathrm{mmol}_{\mathrm{c}} \mathrm{kg}^{-1}$ & 144 & 168 & 163 & 204 & 0.006 & 1267 & 207 & 207 & 197 & 202 & n.s. & 1926 \\
\hline ESP & $\%$ & 60.9 & 70.1 & 73.0 & 70.5 & n.s. & 788 & 60.9 & 68.6 & 60.8 & 48.5 & n.s. & 408 \\
\hline SAR & & 30.7 & 40.1 & 47.8 & 54.6 & 0.0001 & 110 & 50.4 & 66.2 & 56.5 & 34.7 & 0.0001 & 121 \\
\hline Total C & $\mathrm{g} \mathrm{kg}^{-1}$ & 6.11 & 5.55 & 4.77 & 4.13 & 0.001 & 1.12 & 3.18 & 3.87 & 4.35 & 4.77 & 0.0001 & $0.311^{\mathrm{a}}$ \\
\hline Total N & $\mathrm{g} \mathrm{kg}^{-1}$ & 0.484 & 0.500 & 0.443 & 0.421 & 0.06 & 0.0049 & 0.385 & 0.419 & 0.442 & 0.494 & 0.0001 & $0.0020^{\mathrm{a}}$ \\
\hline $\mathrm{CaCO}_{3}$ & $\mathrm{~g} \mathrm{~kg}^{-1}$ & 19.7 & 12.7 & 12.0 & 5.86 & 0.02 & 76.9 & 1.75 & 2.51 & 6.18 & 5.75 & 0.01 & $11.6^{\mathrm{a}}$ \\
\hline Gypsum & $\mathrm{g} \mathrm{kg}^{-1}$ & 50.8 & 59.6 & 58.84 & 65.8 & n.s. & 42.8 & 68.5 & 71.3 & 70.4 & 56.9 & 0.05 & $144^{\mathrm{a}}$ \\
\hline Mo & $\mu \mathrm{gL}^{-1}$ & 467 & 541 & 775 & 812 & 0.09 & 128 & 879 & 848 & 550 & 455 & 0.008 & 94.4 \\
\hline B & $\mathrm{mg} \mathrm{L}^{-1}$ & 15.5 & 17.9 & 21.9 & 21.4 & 0.009 & 20.1 & 24.4 & 24.7 & 19.5 & 18.1 & 0.005 & 20.7 \\
\hline Exchangeable $\mathrm{Na}^{+}$ & $\operatorname{mmol}_{\mathrm{c}} \mathrm{kg}^{-1}$ & 73.5 & 102 & 105 & 130 & 0.001 & 782 & 104 & 125 & 108 & 88.1 & 0.02 & 530 \\
\hline
\end{tabular}

a Field- and plot-scale MSE's are significantly different at the 0.05 level.

b The number of degrees of freedom for each variable is 36/36 (field-scale/plot-scale). 
Table 5

Comparison of field- and plot-scale mean square errors for analyzed soil properties $(0-0.3 \mathrm{~m}$ depth) at the Westlake Study

\begin{tabular}{|c|c|c|c|c|c|c|}
\hline \multirow[t]{2}{*}{ Soil property } & \multirow[t]{2}{*}{ Units } & \multicolumn{2}{|c|}{ Field-scale experiment } & \multicolumn{3}{|c|}{ Plot-scale experiment } \\
\hline & & $\begin{array}{l}4 \mathrm{EC}_{\mathrm{a}} \text { classes } \\
\text { (MS within } \\
\mathrm{EC}_{\mathrm{a}} \text { class) }\end{array}$ & $\begin{array}{l}5 \mathrm{EC}_{\mathrm{a}} \text { classes } \\
\text { (MS within } \\
\mathrm{EC}_{\mathrm{a}} \text { class) }\end{array}$ & $\begin{array}{l}3 \text { Blocks } \\
\text { (MS within block) }\end{array}$ & $\begin{array}{l}4 \text { Blocks } \\
\text { (MS within block) }\end{array}$ & $\begin{array}{l}6 \text { Blocks } \\
\text { (MS within block) }\end{array}$ \\
\hline Water content $\mathrm{t}^{\mathrm{a}}$ & $\mathrm{kg} \mathrm{kg}^{-1}$ & 0.136 & 0.0992 & 0.113 & 0.102 & 0.105 \\
\hline Saturation percentage & $\%$ & 46.7 & 36.1 & 44.9 & 39.4 & 46.4 \\
\hline $\mathrm{pH}$ & & 0.125 & 0.119 & 0.0713 & 0.0666 & 0.0712 \\
\hline $\mathrm{EC}_{\mathrm{e}}$ & $\mathrm{dS} \mathrm{m} \mathrm{m}^{-1}$ & 15.9 & 19.0 & 21.9 & 17.9 & 20.2 \\
\hline CEC & $\mathrm{mmol}_{\mathrm{c}} \mathrm{kg}^{-1}$ & 2111 & 2236 & 3527 & 3704 & 3201 \\
\hline ESP & $\%$ & 399 & 401 & 691 & 583 & 688 \\
\hline SAR & & 92.9 & 103 & 154 & 123 & 154 \\
\hline Total C & $\mathrm{g} \mathrm{kg}^{-1}$ & 3.44 & 3.73 & $1.37^{4,5}$ & $1.87^{5}$ & $0.839^{4,5}$ \\
\hline Total N & $\mathrm{g} \mathrm{kg}^{-1}$ & 0.0214 & 0.0229 & $0.00784^{4,5}$ & $0.00923^{4,5}$ & $0.00712^{4,5}$ \\
\hline $\mathrm{CaCO}_{3}$ & $\mathrm{~g} \mathrm{~kg}^{-1}$ & 92.1 & 91.2 & $14.7^{4,5}$ & $14.6^{4,5}$ & $11.8^{4,5}$ \\
\hline Gypsum & $\mathrm{g} \mathrm{kg}^{-1}$ & 288 & 341 & $172^{5}$ & $159^{5}$ & $163^{5}$ \\
\hline Mo & $\mathrm{mg} \mathrm{L}^{-1}$ & 27.5 & 297 & $94.8^{4,5}$ & $81.9^{4,5}$ & $91.7^{4,5}$ \\
\hline B & $\mathrm{mg} \mathrm{L}^{-1}$ & 33.8 & 35.7 & 27.0 & 25.1 & 25.5 \\
\hline \multicolumn{7}{|c|}{ Anions in the saturation extract } \\
\hline $\mathrm{Cl}^{-}$ & $\operatorname{mmol}_{\mathrm{c}} \mathrm{L}^{-1}$ & 99.4 & 91.5 & 173 & 136 & 172 \\
\hline $\mathrm{HCO}_{3}{ }^{-}$ & $\operatorname{mmol}_{\mathrm{c}} \mathrm{L}^{-1}$ & 0.644 & 0.623 & 0.777 & 0.748 & 0.823 \\
\hline $\mathrm{NO}_{3}^{-}$ & $\operatorname{mmol}_{\mathrm{c}} \mathrm{L}^{-1}$ & 0.0348 & 0.033 & 0.0224 & 0.0222 & 0.0222 \\
\hline $\mathrm{SO}_{4}^{-}$ & $\operatorname{mmol}_{\mathrm{c}} \mathrm{L}^{-1}$ & 2860 & 3404 & 2746 & 2403 & 2471 \\
\hline
\end{tabular}


Cations in the saturation extract

\begin{tabular}{|c|c|c|c|c|c|c|}
\hline $\mathrm{Ca}^{2+}$ & $\operatorname{mmol}_{\mathrm{c}} \mathrm{L}^{-1}$ & 4.16 & 3.91 & 2.43 & 2.27 & 2.57 \\
\hline $\mathrm{K}^{+}$ & $\operatorname{mmol}_{\mathrm{c}} \mathrm{L}^{-1}$ & 0.205 & 0.176 & 0.235 & 0.224 & 0.221 \\
\hline $\mathrm{Mg}^{2+}$ & $\operatorname{mmol}_{\mathrm{c}} \mathrm{L}^{-1}$ & 56.8 & 68.8 & $20.4^{4,5}$ & $20.7^{4,5}$ & $14.1^{4,5}$ \\
\hline $\mathrm{Na}^{+}$ & $\operatorname{mmol}_{\mathrm{c}} \mathrm{L}^{-1}$ & 2986 & 3509 & 3718 & 3107 & 3452 \\
\hline $\mathrm{Ca}^{2+}$ & $\mathrm{mmol}_{\mathrm{c}} \mathrm{kg}^{-1}$ & 1290 & 1034 & $3308^{4,5}$ & $3254^{4,5}$ & $3016^{4,5}$ \\
\hline $\mathrm{K}^{+}$ & $\mathrm{mmol}_{\mathrm{c}} \mathrm{kg}^{-1}$ & 6.62 & 6.88 & $3.20^{4,5}$ & 3.66 & $2.60^{4,5}$ \\
\hline $\mathrm{Mg}^{2+}$ & $\mathrm{mmol}_{\mathrm{c}} \mathrm{kg}^{-1}$ & 171 & 155 & $54.0^{4,5}$ & $48.6^{4,5}$ & $40.8^{4,5}$ \\
\hline $\mathrm{Na}^{+}$ & $\mathrm{mmol}_{\mathrm{c}} \mathrm{kg}^{-1}$ & 852 & 933 & 1209 & 1002 & 1249 \\
\hline
\end{tabular}

Field-scale mean square (MS) is the variance among sites within apparent electrical conductivity $\left(\mathrm{EC}_{\mathrm{a}}\right.$ ) classes, where the field is partitioned into four or five EC $\mathrm{a}_{\mathrm{a}}$ classes.

Plot-scale MS is the variance among sites within blocks, with partitioning of the plot-scale experiment into three, four, and six blocks. ${ }^{4},{ }^{5} \mathrm{Plot}-\mathrm{scale}$ MS's are significantly different from field-scale MS's (0.05 level) with partitioning into four or five $\mathrm{EC}_{\mathrm{a}}$ classes, respectively.

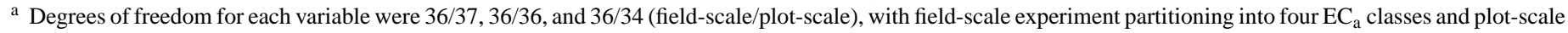
experiment partitioning into three, four, and six blocks, respectively. Degrees of freedom were 35/37, 35/36, and 35/34 (field-scale/plot-scale), with field-scale experiment partitioning into five $\mathrm{EC}_{\mathrm{a}}$ classes and plot-scale experiment partitioning into three, four, and six blocks, respectively. 
and six blocks, are shown in Tables 5 and 6. The MS errors for the majority of measured soil properties were not different $(P \leq 0.05)$ between the two levels of scale. Furthermore, most of those that were different showed only a 2-4-fold disparity, a degree of heterogeneity with little effect on ANOVA (Scheffe, 1959). These findings were similar to those at the FICS site in Colorado (Johnson et al., 2003b).

In general, surface soil MS's (0-0.3 m) compared more favorably between plot- and fieldscale experiments than did MS's for soil properties evaluated at deeper depths $(0-1.2 \mathrm{~m})$ (Tables 5 and 6). This is likely a reflection of increasing heterogeneity with depth at WLF (Corwin et al., 2003b), but is contrary to findings at the FICS in Colorado where variability is greatest at the soil surface (Johnson et al., 2003b). The MS's for soil properties in surface soils (0-0.3 m depth) were most alike when field- and plot-scale experiments were partitioned into four $\mathrm{EC}_{\mathrm{a}}$ classes and four blocks, respectively (Table 5). The number of surface soil properties showing different MS's at the field and plot scales increased when the number of $\mathrm{EC}_{\mathrm{a}}$ classes was increased from four to five.

As was true for surface soils, MS's for deeper soil (0-1.2 m) properties were most similar between field- and plot-scale experiments when the experimental sites were partitioned into four $\mathrm{EC}_{\mathrm{a}}$ classes and four blocks, respectively (Tables 5 and 6). The MS comparisons changed little when partitioning was increased from four to five $\mathrm{EC}_{\mathrm{a}}$ classes with four plotscale blocks. Only extractable $\mathrm{Na}^{+}$was added to the list of soil properties with different MS's between the two levels of scale.

The MS for $\mathrm{EC}_{\mathrm{e}}$ was expected to compare favorably between the field and plot scales, since $\mathrm{EC}_{\mathrm{e}}$ was the basis for plot-scale blocking and the major contributor to measured $\mathrm{EC}_{\mathrm{a}}$ at WLF (Corwin et al., 2003b). This was confirmed for surface soils where soil water content, SP, and B, all highly correlated with $\mathrm{EC}_{\mathrm{e}}$ (Corwin et al., 2003b), also showed comparable MS's between the field- and plot-scale experiments. Interestingly, these relationships were not as strong at deeper soil depths. Comparisons of field- and plot-scale MS's for $\mathrm{EC}_{\mathrm{e}}$ (four or five $\mathrm{EC}_{\mathrm{a}}$ classes versus three or six $\mathrm{EC}_{\mathrm{e}}$ blocks) and $\mathrm{SP}$ (four or five $\mathrm{EC}_{\mathrm{a}}$ classes versus six $\mathrm{EC}_{\mathrm{e}}$ blocks) revealed significant differences. This may reflect the increasing $\mathrm{EC}_{\mathrm{e}}$ and soil heterogeneity found with depth by Corwin et al. (2003b). It is also possible that spatial patterns in salinity changed slightly between 1999, when soils were $\mathrm{EC}_{\mathrm{a}}$ mapped, and 2002 when soils were sampled (Johnson et al., 2003a).

\subsection{Field-scale within-field blocking versus traditional plot-scale blocking}

In a traditional randomized complete block design, blocks are positioned to frame homogeneous regions in a field. Two or more blocks may include soils with similar characteristics as was the case with each of the salinity-based blocking schemes used for the WLF plotscale site (Fig. 2B). For example, when apportioned into four blocks, the $\mathrm{EC}_{\mathrm{e}}$ map shows block 2 to be highest in salinity, block 4 lowest, and blocks 1 and 3 of similar mid-range salinity. This is verified by soil analyses (Table 4).

In contrast, the soil property means within $\mathrm{EC}_{\mathrm{a}}$ classes were directionally stratified for most properties examined, indicating a degree of linearity between those properties and $\mathrm{EC}_{\mathrm{a}}$ (Table 4). Total $\mathrm{C}$ and $\mathrm{N}$, soil properties associated with yield potential, were negatively correlated with $\mathrm{EC}_{\mathrm{a}}$ at one or both depths of measurement. Properties indicative of increased salinity and decreased yield ( $\mathrm{SP}, \mathrm{pH}, \mathrm{EC}_{\mathrm{e}}, \mathrm{CEC}$, ESP, sodium adsorption ratio (SAR), B, 
Table 6

Comparison of field- and plot-scale mean square errors for analyzed soil properties (0-1.2 m depth) at the Westlake Study

\begin{tabular}{|c|c|c|c|c|c|c|}
\hline \multirow[t]{2}{*}{ Soil property } & \multirow[t]{2}{*}{ Units } & \multicolumn{2}{|l|}{ Field-scale experiment } & \multicolumn{3}{|c|}{ Plot-scale experiment } \\
\hline & & $\begin{array}{l}4 \mathrm{EC}_{\mathrm{a}} \text { classes } \\
\text { (MS within } \mathrm{EC}_{\mathrm{a}} \text { class) }\end{array}$ & $\begin{array}{l}5 \mathrm{EC}_{\mathrm{a}} \text { classes } \\
\left(\mathrm{MS} \text { within } \mathrm{EC}_{\mathrm{a}} \text { class }\right)\end{array}$ & $\begin{array}{l}3 \text { Blocks } \\
\text { (MS within block) }\end{array}$ & $\begin{array}{l}4 \text { Blocks } \\
\text { (MS within block) }\end{array}$ & $\begin{array}{l}6 \text { Blocks } \\
\text { (MS within block) }\end{array}$ \\
\hline Water content ${ }^{\mathrm{a}}$ & $\mathrm{kg} \mathrm{kg}^{-1}$ & 0.0845 & 0.0748 & 0.0486 & 0.0497 & 0.0441 \\
\hline Saturation percentage & $\%$ & 64.0 & 56.6 & 34.3 & 35.9 & $27.0^{4,5}$ \\
\hline $\mathrm{pH}$ & & 0.0316 & 0.0322 & 0.0288 & 0.0275 & 0.0259 \\
\hline $\mathrm{EC}_{\mathrm{e}}$ & $\mathrm{dS} \mathrm{m} \mathrm{m}^{-1}$ & 16.7 & 11.9 & $26.8^{4,5}$ & 20.0 & $25.0^{4,5}$ \\
\hline CEC & $\operatorname{mmol}_{\mathrm{c}} \mathrm{kg}^{-1}$ & 1267 & 1471 & 1801 & 1926 & 1471 \\
\hline SAR & & 111 & 79.1 & $165^{5}$ & 121 & $166^{5}$ \\
\hline Total C & $\mathrm{g} \mathrm{kg}^{-1}$ & 1.12 & 1.31 & $0.278^{4,5}$ & $0.311^{4,5}$ & $0.264^{4,5}$ \\
\hline Total N & $\mathrm{g} \mathrm{kg}^{-1}$ & 0.00489 & 0.00479 & $0.0020^{4,5}$ & $0.0020^{4,5}$ & $0.0021^{4,5}$ \\
\hline $\mathrm{CaCO}_{3}$ & $\mathrm{~g} \mathrm{~kg}^{-1}$ & 76.9 & 86.6 & $11.0^{4,5}$ & $11.6^{4,5}$ & $8.16^{4,5}$ \\
\hline Gypsum & $\mathrm{g} \mathrm{kg}^{-1}$ & 428 & 396 & $119^{4,5}$ & $144^{4,5}$ & $128^{4,5}$ \\
\hline Mo & $\mathrm{mg} \mathrm{L}^{-1}$ & 127 & 130 & 93.5 & 94.4 & 78.6 \\
\hline B & $\mathrm{mg} \mathrm{L}^{-1}$ & 20.1 & 20.8 & 22.5 & 20.7 & 21.2 \\
\hline $\mathrm{Cl}^{-}$ & $\mathrm{mmol}_{\mathrm{c}} \mathrm{L}^{-1}$ & 224 & 203 & 206 & 173 & 211 \\
\hline $\mathrm{HCO}_{3}{ }^{-}$ & $\mathrm{mmol}_{\mathrm{c}} \mathrm{L}^{-1}$ & 0.126 & 0.120 & $0.330^{4,5}$ & $0.279^{4,5}$ & $0.356^{4,5}$ \\
\hline $\mathrm{NO}_{3}{ }^{-}$ & $\mathrm{mmol}_{\mathrm{c}} \mathrm{L}^{-1}$ & 0.0170 & 0.0174 & $0.490^{4,5}$ & $0.515^{4,5}$ & $0.519^{4,5}$ \\
\hline $\mathrm{SO}_{4}^{-}$ & $\operatorname{mmol}_{\mathrm{c}} \mathrm{L}^{-1}$ & 2505 & 1771 & $7252^{4,5}$ & $5949^{4,5}$ & $6682^{4,5}$ \\
\hline
\end{tabular}


Table 6 (Continued)

\begin{tabular}{|c|c|c|c|c|c|c|}
\hline \multirow[t]{2}{*}{ Soil property } & \multirow[t]{2}{*}{ Units } & \multicolumn{2}{|l|}{ Field-scale experiment } & \multicolumn{3}{|c|}{ Plot-scale experiment } \\
\hline & & $\begin{array}{l}4 \mathrm{EC}_{\mathrm{a}} \text { classes } \\
\text { (MS within } \mathrm{EC}_{\mathrm{a}} \text { class) }\end{array}$ & $\begin{array}{l}5 \mathrm{EC}_{\mathrm{a}} \text { classes } \\
\text { (MS within } \mathrm{EC}_{\mathrm{a}} \text { class) }\end{array}$ & $\begin{array}{l}3 \text { Blocks } \\
\text { (MS within block) }\end{array}$ & $\begin{array}{l}4 \text { Blocks } \\
\text { (MS within block) }\end{array}$ & $\begin{array}{l}6 \text { Blocks } \\
\text { (MS within block) }\end{array}$ \\
\hline \multicolumn{7}{|c|}{ Cations in the saturation extract } \\
\hline $\mathrm{Ca}^{2+}$ & $\mathrm{mmol}_{\mathrm{C}} \mathrm{L}^{-1}$ & 2.07 & 2.00 & $5.07^{4,5}$ & $4.74^{4,5}$ & $5.20^{4,5}$ \\
\hline $\mathrm{K}^{+}$ & $\mathrm{mmol}_{\mathrm{C}} \mathrm{L}^{-1}$ & 0.162 & 0.105 & $0.356^{4,5}$ & $0.312^{4,5}$ & $0.329^{4,5}$ \\
\hline $\mathrm{Mg}^{2+}$ & $\mathrm{mmol}_{\mathrm{C}} \mathrm{L}^{-1}$ & 27.3 & 31.6 & $99.7^{4,5}$ & $89.9^{4,5}$ & $68.3^{4,5}$ \\
\hline $\mathrm{Na}^{+}$ & $\mathrm{mmol}_{\mathrm{c}} \mathrm{L}^{-1}$ & 3209 & 2230 & $7771^{4,5}$ & $6146^{5}$ & $7362^{4,5}$ \\
\hline \multicolumn{7}{|c|}{ Exchangeable cations } \\
\hline $\mathrm{Ca}^{2+}$ & $\mathrm{mmol}_{\mathrm{c}} \mathrm{kg}^{-1}$ & 446 & 411 & $1098^{4,5}$ & $1199^{4,5}$ & $1111^{4,5}$ \\
\hline $\mathrm{K}^{+}$ & $\mathrm{mmol}_{\mathrm{c}} \mathrm{kg}^{-1}$ & 2.11 & 2.06 & $0.740^{4,5}$ & $0.842^{4,5}$ & $0.690^{4,5}$ \\
\hline $\mathrm{Mg}^{2+}$ & $\mathrm{mmol}_{\mathrm{c}} \mathrm{kg}^{-1}$ & 151 & 160 & 89.8 & 82.5 & $61.6^{4,5}$ \\
\hline $\mathrm{Na}^{+}$ & $\mathrm{mmol}_{\mathrm{c}} \mathrm{kg}^{-1}$ & 782 & 580 & 604 & 530 & 611 \\
\hline
\end{tabular}

Field-scale mean square (MS) is the variance among sites within apparent electrical conductivity $\left(\mathrm{EC}_{\mathrm{a}}\right.$ ) classes, where the field is partitioned into four or five EC $\mathrm{a}_{\mathrm{a}}$ classes. Plot-scale MS is the variance among sites within blocks, with partitioning of the plot-scale experiment into three, four, and six blocks. ${ }^{4,5}$ Plot-scale MS's are significantly different from field-scale MS's (0.05 level) with partitioning into four or five $\mathrm{EC}_{\mathrm{a}}$ classes, respectively.

${ }^{a}$ Degrees of freedom for each variable were 36/37,36/36, and 36/34 (field-scale/plot-scale), with field-scale experiment partitioning into four EC $\mathrm{a}_{\mathrm{a}}$ classes and plot-scale experiment partitioning into three, four, and six blocks, respectively. Degrees of freedom were 35/37, 35/36, and 35/34 (field-scale/plot-scale), with field-scale experiment partitioning into five $\mathrm{EC}_{\mathrm{a}}$ classes and plot-scale experiment partitioning into three, four, and six blocks, respectively. 
and exchangeable $\mathrm{Na}$ ) were positively correlated with $\mathrm{EC}_{\mathrm{a}}$. Although relationships between specific soil properties and yield potential at the FICS in Colorado are quite different from those of WLF, similar directional stratification of soil properties by $\mathrm{EC}_{\mathrm{a}}$ classification was identified (Table 1). In other soils, $\mathrm{EC}_{\mathrm{a}}$ predicts yield in a non-linear fashion, where yield is maximized at mid-range $\mathrm{EC}_{\mathrm{a}}$ values (Kitchen et al., 1999).

Another important distinction must be made between $\mathrm{EC}_{\mathrm{a}}$-classified within-field blocking and traditional randomized complete block designs. Traditional blocks are defined as grouped sets of experimental units to which treatments are independently applied. As a result, each block encompasses several experimental units. In contrast, with $\mathrm{EC}_{\mathrm{a}}$-classified within-field blocking each treatment is independently applied to a field, where a field is the experimental unit. Each experimental unit encompasses several blocks; hence, the term within-field blocking.

There are frequently limitations associated with conducting an experiment based upon an existing dataset. In this study, a response surface model was applied to identify $\mathrm{EC}_{\mathrm{a}}$ classes at WLF because it was the basis previously established to identify soil sampling sites for the data set examined. The response surface approach favors the identification of soil sampling sites at the extremes of $\mathrm{EC}_{\mathrm{a}}$ (personal communication, Scott Lesch) and may not be the optimal method for classifying soils for the purpose of blocking (to minimize within-class variance). Yet, despite this possible deficiency MS errors for most soil properties were similar between field-scale $\mathrm{EC}_{\mathrm{a}}$-classified and plot-scale salinity-based blocking schemes. It is possible that field- and plot-scale variances at WLF would show even greater similarity had unsupervised $\mathrm{EC}_{\mathrm{a}}$ classification methods been applied as at the FICS in Colorado.

By the same token, the plot-scale study was positioned in a location predetermined by the availability of soil analyses from randomly-selected sampling sites at WLF. More homogeneous blocks may have been possible in another location. Analyses made in this study should be regarded as reasonable estimates of field- and plot-scale experimental errors for WLF.

\section{Conclusions}

At WLF in the San Joaquin Valley of central California, $\mathrm{EC}_{\mathrm{a}}$ classification significantly delineated a majority of soil factors tested and effectively reduced their variance. Additionally, field-scale $\mathrm{EC}_{\mathrm{a}}$-classified MS (within-field) variability and traditional plot-scale MS error were found to be similar. These findings corroborate those from the FICS in Colorado (Johnson et al., 2003b), reinforcing the proposal that $\mathrm{EC}_{\mathrm{a}}$-classified within-field blocking can be used for the statistical design of field-scale studies and as a means to estimate plot-scale experimental error. The fact that the Colorado and California experimental sites exemplify widely contrasting climates, cropping systems, soil characteristics, production challenges, and $\mathrm{EC}_{\mathrm{a}}$ classification methods further bolsters the potential application of this alternative statistical approach.

It is important to note that $\mathrm{EC}_{\mathrm{a}}$ classification can be used as a basis for blocking only when $\mathrm{EC}_{\mathrm{a}}$ and yield are correlated, a relationship found in locations where the soil characteristics driving $\mathrm{EC}_{\mathrm{a}}$ also limit yield. At WLF, salinity dominated measured $\mathrm{EC}_{\mathrm{a}}$ and best predicted 
yield, while at the FICS clay content drove $\mathrm{EC}_{\mathrm{a}}$ and defined erosion phase/yield potential across fields. Although $\mathrm{EC}_{\mathrm{a}}$ and yield are not always correlated (Kitchen et al., 1999; Johnson et al., 2003a), the $\mathrm{EC}_{\mathrm{a}}$-yield relationship has been documented in multiple locations within and outside the U.S. (Kitchen et al., 1999, 2003; Johnson et al., 2003a; Veris Technologies, 2004). This indicates widespread potential application for $\mathrm{EC}_{\mathrm{a}}$ in experimental design and analysis.

Within-field blocking, based on $\mathrm{EC}_{\mathrm{a}}$, offers a compelling tool in statistical design. It is well suited for examining environmental response (soil, water, and atmosphere) to a single treatment or management practice and provides a foundation for the study of these responses within a spatial context. For instance, the impact of management on soil quality could be evaluated across a gradient of soil fertility delimited by $\mathrm{EC}_{\mathrm{a}}$ classes.

Within-field blocking also offers the opportunity to compare two or more treatments without benefit of replication. Many landowners are understandably hesitant to commit multiple fields and ongoing management to create replicated treatments in on-farm experiments. However, when multiple replicated treatments are not feasible, landowners may be willing to split a field into two parcels to provide room for one additional treatment. Within-field blocking, based on $\mathrm{EC}_{\mathrm{a}}$ classification, could then be used to roughly compare the two treatments. Two or three treatments could also be applied to separate fields that could be roughly compared using this approach. In agronomic research, the opportunity to add one or more additional treatments can significantly improve the potential value of an experiment.

Wide-spread acceptance of within-field blocking as a bonafide statistical design will require its continued assessment over space and time. In order to broaden the scope of inference beyond the WLF and FICS, multi-site comparisons of field- and plot-scale experimental error are necessary. For this reason, we take a conservative stance, suggesting that $\mathrm{EC}_{\mathrm{a}}$-classified within-field variance be used in a systems approach to agronomic research, as a rough estimate of plot-scale experimental error and a means to identify questions requiring further research at the plot scale. Such alternative statistical methods will encourage the study of intact agroecosystems that are realistic in terms of scale, management, farm equipment, and soil heterogeneity. Because farmers can relate to experimental goals examined in systems similar to their own, field-scale experiments may also lead to greater acceptance and implementation of sustainable management practices.

\section{Acknowledgements}

The authors wish to acknowledge the University of California Kearney Foundation of Soil Science and the University of California Salinity-Drainage program for the funds that supported the chemical analyses of the soil core samples. Ceil Howe, Jr., and Ceil Howe III provided the site. The authors thank Nahid Vishteh and Harry Forster for their analytical technical support, James Wood for his help in collecting soil core samples, and especially acknowledge the conscientious work and diligence of Clay Wilkinson and Derrick Lai who performed the preparation and chemical analysis of the soil samples. Thanks are also extended to Scott Lesch for technical expertise and assistance with $\mathrm{EC}_{\mathrm{a}}$ classification of the Westlake Farms site. 


\section{References}

Corwin, D.L., Lesch, S.M., 2003. Application of soil EC to precision agriculture: theory, principles, and guidelines. Agron. J. 95, 455-471.

Corwin, D.L., Carrillo, M.L.K., Vaughan, P.J., Rhoades, J.D., Cone, D.G., 1999. Evaluation of a GIS-linked model of salt loading to groundwater. J. Environ. Qual. 28, 471-480.

Corwin, D.L., Kaffka, S.R., Hopmans, J.W., Mori, Y., van Groenigen, J.W., van Kessel, C., Lesch, S.M., Oster, J.D., 2003a. Assessment and field-scale mapping of soil quality properties of a saline-sodic soil. Geoderma 1952, 1-29.

Corwin, D.L., Lesch, S.M., Shouse, P.J., Soppe, R., Ayars, J.E., 2003b. Identifying soil properties that influence cotton yield using soil sampling directed by apparent soil electrical conductivity. Agron. J. 95, 352-364.

Crawford, C.A., Bullock, D.G., Pierce, F.J., Stroup, W.W., Hergert, G.W., Eskridge, K.M., 1997. Experimental design issues and statistical evaluation techniques for site-specific management. In: The State of Site-Specific Management for Agriculture. American Society of Agronomy, Madison, WI, pp. 301-335.

Drinkwater, L.E., 2002. Cropping systems research: reconsidering agricultural experimental approaches. Hort. Technol. 12 (3), 355-361.

Fraisse, C.W., Sudduth, K.A., Kitchen, N.R., 2001. Delineation of site-specific management zones by unsupervised classification of topographic attributes and soil electrical conductivity. Trans. ASAE 44 (1), 155-166.

Hargrove, W.W., Pickering, J., 1992. Pseudoreplication: a sine qua non for regional ecology. Landscape Ecol. 6, 251-258.

Harris, J.A., 1915. On a criterion of substratum homogeneity (or heterogeneity) in field experiments. Am. Nat. 49, 430-454.

Johnson, C.K., Doran, J.W., Duke, H.R., Wienhold, B.J., Eskridge, K.M., Shanahan, J.F., 2001. Field-scale electrical conductivity mapping for delineating soil condition. Soil Sci. Soc. Am. J. 65, 1829-1837.

Johnson, C.K., Doran, J.W., Eghball, B., Eigenberg, R.A., Wienhold, B.J., Woodbury, B.L., 2003a. Status of soil electrical conductivity studies by central states researchers. American Society of Agricultural Engineers Annual International Meeting, Las Vegas, NV, Paper No. 032339.

Johnson, C.K., Eskridge, K.M., Wienhold, B.J., Doran, J.W., Peterson, G.A., Buchleiter, G.W., 2003b. Using electrical conductivity classification and within-field variability to design field-scale research. Agron. J. 95, 602-613.

Johnson, C.K., Mortensen, D.A., Wienhold, B.J., Shanahan, J.F., Doran, J.W., 2003c. Site-specific management zones based on soil electrical conductivity in a semiarid cropping system. Agron. J. 95, 303-315.

Johnson, C.K., Drijber, R.A., Wienhold, B.J., Wright, S.F., Doran, J.W., 2004. Linking microbial-scale findings to farm-scale outcomes in a dryland cropping. Precision Agric. 5, 311-328.

Kitchen, N.R., Sudduth, K.A., Drummond, S.T., 1999. Soil electrical conductivity as a crop productivity measure for claypan soils. J. Prod. Agric. 12, 607-617.

Kitchen, N.R., Drummond, S.T., Lund, E.D., Sudduth, K.A., Buchleiter, G.W., 2003. Soil electrical conductivity and topography related to yield for three contrasting soil-crop systems. Agron. J. 95, 483-495.

LeClerg, E.L., Leonard, W.H., Clark, A.G., 1962. Field Plot Technique, second ed. Burgess Publishing Co., Minneapolis, MN.

Lesch, S.M., Strauss, D.J., Rhoades, J.D., 1995. Spatial prediction of soil salinity using electromagnetic induction techniques: 2. An efficient spatial sampling algorithm suitable for multiple linear regression model identification and estimation. Water Resour. Res. 31, 387-398.

Mueller, J.P., Barbercheck, M.E., Bell, M., Brownie, C., Creamer, N.G., Hu, S., Kin, L., Linker, H.M., Louws, F.J., Marra, M., Mueller, J.P., Raczkowski, C.W., Susko, D., Wagger, M.G., 2002. Implementation of long-term agricultural systems studies: challenges and opportunities. Hort. Technol. 12 (3), 362-368.

Nielsen, D.R., Wendroth, O., Parlange, M.B., 1995. Opportunities for examining on-farm soil variability. In: Site-Specific Management for Agricultural Systems. American Society of Agronomy, Madison, WI, pp. 95132.

Peterson, G.A., Westfall, D.G., Cole, C.V., 1993. Agroecosystem approach to soil and crop management research. Soil Sci. Soc. Am. J. 57, 1354-1360.

Rhoades, J.D., Manteghi, N.A., Shouse, P.J., Alves, W.J., 1989. Soil electrical conductivity and soil salinity: new formulations and calibrations. Soil Sci. Soc. Am. J. 53, 433-439. 
Rzewnicki, P.E., Thompson, R., Lesoing, G.W., Elmore, R.W., Francis, C.A., Parkhurst, A.M., Moomaw, R.S., 1988. On-farm experiment designs and implications for locating research sites. Am. J. Alt. Agric. 3, 168-173.

Rzewnicki, P., 1991. Farmer's perceptions of experiment station research, demonstrations, and on-farm research in agronomy. J. Agron. Educ. 20, 31-36.

SAS Institute, 1997. SAS/STAT Software: changes and enhancements through Release 6.12. Cary, NC, 1997.

Scheffe, H., 1959. The Analysis of Variance. Wiley, New York, NY.

Stroup, W.W., Hildebrand, P.E., Francis, C.A., 1993. Farmer participation for more effective research in sustainable agriculture. In: Technologies for Sustainable Agriculture in the Tropics. American Society of Agronomy Special Publishers 56, Madison, WI, pp. 153-186.

Sumberg, J., Okali, C., 1988. Farmers, on-farm research and the development of new technology. Exp. Agric. 24, 333-342.

Vanden Heuvel, R.M., 1996. The promise of precision agriculture. J. Soil Water Conserv. 51, 38-40.

Veris Technologies, 2004. [Online]. [2 p.] Available at: http://www.veristech.com [cited 31 July 2004; verified 31 July 2004]. Veris Technologies, Salina, KS. 